\title{
Genetic parameters of milk productivity for three lactations of Holstein cattle with different genotypes of LEP gene
}

\author{
Tahir M. Akhmetov ${ }^{1, *}$, Natalia Yu. Safina ${ }^{2}$, Azat M. Alimov ${ }^{1}$ and Margarita I. Varlamova ${ }^{1,2}$ \\ ${ }^{1}$ N.E. Bauman Kazan State Academy of Veterinary Medicine, Kazan 420029, Russia \\ ${ }^{2}$ Tatar Scientific Research Institute of Agriculture - Subdivision of the Federal State Budgetary Institution of Science "Kazan Scientific \\ Center of Russia Academy of Sciences, Kazan 420059, Russia
}

\begin{abstract}
The research presents the findings of DNA testing of allelic polymorphism by the AC-PCR method of the LEP gene. The research was conducted among 172 Holstein cows at Integrated Agricultural Production Centre "Stud farm named after Lenin" in Atninsky district of the Republic of Tatarstan in 2017-2018. All genotypes of the LEP gene were identified through the research. Associations of the leptin gene polymorphism with dynamics of milk production during three lactations of Holstein cows were established. The best indicators for all three lactations were found in a group of animals with the TT genotype of the LEP gene. These individuals are characterized by increased milk yield, a high yield index, and tend to increase the average daily milk yield during three lactations. These individuals are characterized by increased milk yield, a high milk yield index, and tend to increase the average daily milk yield during three lactations.
\end{abstract}

\section{Introduction}

Human breeding of any animal species pursues one goal - to obtain and reproduce individuals with the specified properties [1]. To make the best use of genetic data, it must be combined with traditional information sources. Genetic selection, i.e. the use of functional mutations directly responsible for differences in phenotypes, is currently the most effective marker selection option.

It is believed that the increase in cow productivity occurs before 4-5 lactations. However, in recent years, due to changes in the genotype of animals due to the improvement of native species and changes in the approach to the use of animals in industrial milk production technology, the average duration of productive longevity of dairy cattle has decreased to 2.6 lactations and continues to decrease. This is all about rate of animal use. In this regard, the question of the influence of animal age on the milk production of cows becomes interesting for practitioners of dairy cattle breeding [2,3].

The leptin gene and its polymorphic variants of alleles and genotypes can be considered as one of the potential markers of milk and meat production [4]. Leptin is interesting for breeding because it largely determines the milk production of cattle, the content of components in milk (protein and fat), and, just as important, it is associated with the productive longevity of livestock animals [5].

The leptin gene (LEP) is a non-glycolized $16 \mathrm{kDa}$ polypeptide that signals fat deposits and the energy status of the hypothalamus [6]. In cattle, the LEP gene is located on chromosome 4 [7]. It consists of 3 exons and 2 introns, only 2 exons of which are transmitted to the protein [8].

Structurally, the leptin gene is a protein consisting of 167 amino acids and including 21 amino acid signal sequences [9]. The polymorphism associated with the LEP $(\mathrm{T} \rightarrow \mathrm{C})$ mutation leads to the replacement of cysteine with arginine in the $\alpha$-helix of the leptin polypeptide [10]. It is identified in the coding region at position 73 [7].

The work objective was to characterize cows with different genotypes of the leptin gene for milk production during 3 lactations.

\section{Materials and Methods}

The scientific and economic experiment took place at the premises of Integrated Agricultural Production Centre "Stud farm named after Lenin" in Atninsky district of the Republic of Tatarstan. 172 Holstein cows were selected for the research. During the experiment all animals were kept under equal environmental conditions on a standard diet, with proper care, with normal veterinary and technological attendance, in a farm that was safe for infectious and invasive diseases.

Laboratory research was conducted in the Department of agrobiological research of Tatar Scientific Research Institute of Agriculture - Subdivision of the Federal State Budgetary Institution of Science "Kazan Scientific Center of the Russian Academy of Sciences".

* Corresponding author: ahmetov-tahir@mail.ru 
The analysis of the origin, physical development, body weight, milk production and lactational activity of experimental animals was carried out according to data obtained from the official electronic file on the herd "SELEX w. 6.01" (AWS Plinor, Russia).

172 samples of whole blood were taken from the tail vein of Holstein cows during the work for DNA testing of allelic polymorphism of genetic markers of economic characteristics of cattle. The biomaterial was collected in K-3 EDTA preservative tubes containing the anticoagulant (APEXLAB, China).

DNA purification from whole blood of cattle was carried out using a ready-made set of "Ampli Prime" DNA-Sorb-B (Next Bio, Russia) in accordance with the manufacturer's instruction.

The AC-PCR method was used to analyze SNP in the 2 exon of the leptin gene (LEP), in which both alleles are amplified simultaneously, and then identified by the size of their fragments in gel electrophoresis [11-13]. A mixture of reagents containing $2 \mu$ of purified DNA, 2 $\mu l$ of dNTPs, $0.2 \mu l$ of Taq DNA polymerase, $2 \mu l$ of the buffer supplied with it, as well as a set of oligonucleotide primers were prepared for PCR with a given sequence:

$$
\text { F1: }
$$

$$
5 \text {, }
$$

GACGATGTGCCACGTGTGGTTTCTTCTGT - 3'

$$
\text { R1: }
$$$$
5 \text {, }
$$

CGGTTCTACCTCGTCTCCCAGTCCCTCC - 3'

$$
\text { F2: }
$$

$$
5 \text {, }
$$

TGTCTTACGTGGAGGCTGTGCCCAGCT - 3'

$$
\mathrm{R} 2 \text { : }
$$

5 ,

\section{AGGGTTTGGGTGTCATCCTGGACCTTTCG - 3'.}

Amplification of fragments was carried out on programmable thermocyclers "T-100 Thermal Cycler" and "My Cycler" (BIO RAD, USA) at the optimal temperature-time mode developed for a set of primers. Preliminary denaturation took 5 minutes at $94{ }^{\circ} \mathrm{C}$ followed by 40 cycles: denaturation at $94{ }^{\circ} \mathrm{C}$ for $10 \mathrm{sec}$, annealing at $60{ }^{\circ} \mathrm{C}$ for $10 \mathrm{sec}$, extension at $72{ }^{\circ} \mathrm{C}$ for 10 sec, and final extension at $72{ }^{\circ} \mathrm{C}$ for $10 \mathrm{~min}$. Electrophoretic separation was in a $2.6 \%$ agarose gel at field strength of $20 \mathrm{~V} / \mathrm{cm}$ for 25 minutes with $1 \%$ ethidium bromide in $1 \times$ TBE buffer.

The effect of electric current separates amplified and restriction fragments by molecular weight. Visualization, video recording and documentation were carried out using a UV transilluminator and a Gel\&Doc system (BIO-RAD, USA). Identification of genotypes was determined by the detectable polymorphism of DNA sequences.

\section{Results and Discussion}

Two alleles and three genotypes of the LEP gene were identified as a result of the polymerase chain reaction. An electrophoregram in an agarose gel showed a combination of fragments, depending on the animal genotype. Different genotypes are represented by the following number of bases: CC - 164 and 239 bp; TC - 131, 164 and 239 bp; TT - 131 and 239 bp. According to the DNA detection data of 172 cows, it was found that the studied livestock is polymorphic by the leptin gene. The $\mathrm{C}$ and $\mathrm{T}$ alleles were distributed as 0.616 and 0.384 , respectively; the CC genotype was $35.5 \%$ (61 animals), the TC genotype - 52.3\% (90 animals), and the TT genotype - $12.2 \%$ (21 animals).

The chi-square test of the difference between the observed and expected distribution found that the value of $\chi^{2}=1.95$ is lower than the critical value $\left(\chi_{\text {crit }}=5.99 ; p\right.$ $<0.05)$. Under the Hardy-Weinberg principle, genetic equilibrium is not disturbed in the population of interest according to the LEP gene. Milk production research for three lactations was carried out taking into account the established genotype of the leptin gene.

Our previous studies [14] showed that following the results of the first lactation, cows with the LEP ${ }^{\mathrm{TT}}$ genotype had a significant advantage in milk production for 305 days of milk yield, the difference with herd mates with the LEP ${ }^{\mathrm{TC}}$ genotype was $673.4 \mathrm{~kg}(8.9 \%$; $\mathrm{p}<0.01)$, with the LEPCC genotype $-459.1 \mathrm{~kg}(6.1 \%)$ (Table 1).

The same group of individuals compared favorably during the second and third lactation. Heterozygous TCanimals were characterized by minimal milk yield during all three standard lactations. The average milk yield for the 1 st and 2nd lactation (305 days) between cows with different genotypes of the LEP gene differed slightly and had no statistical significance.

The third lactation was shortened, the advantage in milk yield of cows with the TT genotype was $941.5 \mathrm{~kg}$ $(11.5 \% ; \mathrm{p}<0.05)$ over animals with the TC genotype and $1329.2 \mathrm{~kg}(16.2 \%$; $<0.01)$ over homozygous CCindividuals.

A similar tendency was observed based on the findings of full lactations. The highest milk production in the 1st, 2nd and 3rd lactation was also found in cows with the homozygous TT genotype of the leptin gene. During the first and second lactation, there were no statistically significant differences between groups with different genotypes of the LEP gene.

But in comparison with the amount of milk produced from cows with the TC and CC genotypes for the third full lactation, the significant difference with the milk yield of cows with the TT genotype was 941.5 (11.5\%; $\mathrm{p}<0.05) \mathrm{kg}$ and $1329.2 \mathrm{~kg}(16.2 \% ; \mathrm{p}<0.01)$, respectively.

The milk yield index of cows with the TT genotype compared favorably with this indicator in herd mates with other genotypes of the LEP gene following the results of all three lactations. The significant difference for the second lactation between the groups with TT and CC genotypes was $144.9 \mathrm{~kg}(9.9 \% ; \mathrm{p}<0.01)$, and for the third one $-166.3 \mathrm{~kg}(11.2 \%$; $<0.001)$. 
Table 1. Milk productivity for the three lactation

\begin{tabular}{|c|c|c|c|}
\hline \multirow{2}{*}{ Traits } & \multicolumn{3}{|c|}{ Genotype } \\
\hline & $C C(\mathrm{n}=61)$ & $T C(\mathrm{n}=90)$ & $T T(\mathrm{n}=21)$ \\
\hline \multicolumn{4}{|c|}{ I lactation } \\
\hline 305-day milk yield, kg & $7073.5 \pm 117.4$ & $6859.2 \pm 139.4$ & $7532.6 \pm 235.7^{* * *}$ \\
\hline Lactation milk yield, $\mathrm{kg}$ & $8391.8 \pm 248.7$ & $8041.3 \pm 295.2$ & $8778.2 \pm 297.8$ \\
\hline Lactation length, days & $366.9 \pm 10.8$ & $364.3 \pm 10.7$ & $363.1 \pm 15.9$ \\
\hline Milking index & $1349.4 \pm 29.0$ & $1326.2 \pm 28.9$ & $1468.3 \pm 54.3^{* * *}$ \\
\hline One day lactation milk yield, kg & $22.9 \pm 0.3^{*}$ & $22.1 \pm 0.2$ & $24.2 \pm 0.4^{* * * *}$ \\
\hline \multicolumn{4}{|c|}{ II lactation } \\
\hline 305-day milk yield, kg & $8059.0 \pm 171.5$ & $7719.9 \pm 154.8$ & $8222.9 \pm 287.5$ \\
\hline Lactation milk yield, $\mathrm{kg}$ & $8969.0 \pm 287.9$ & $8438.2 \pm 242.0$ & $9155.7 \pm 418.8$ \\
\hline Lactation length, days & $1324.7 \pm 31.8$ & $1380.1 \pm 33.9$ & $1469.6 \pm 30.4^{* *}$ \\
\hline Milking index & $357.1 \pm 10.0$ & $364.1 \pm 14.6$ & $357.3 \pm 9.2$ \\
\hline One day lactation milk yield, $\mathrm{kg}$ & $25.1 \pm 0.4^{* * * *}$ & $23.2 \pm 0.3$ & $25.6 \pm 0.5^{* * * *}$ \\
\hline \multicolumn{4}{|c|}{ III lactation } \\
\hline 305-day milk yield, kg & $6883.8 \pm 326.8$ & $7271.5 \pm 259.9$ & $8213.0 \pm 321.6^{* *}$ \\
\hline Lactation milk yield, $\mathrm{kg}$ & $6883.8 \pm 326.8$ & $7271.5 \pm 259.9$ & $8213.0 \pm 321.6^{* *}$ \\
\hline Lactation length, days & $1321.1 \pm 30.5$ & $1421.9 \pm 30.3^{*}$ & $1487.4 \pm 38.6^{* * *}$ \\
\hline Milking index & $271.8 \pm 12.6$ & $290.4 \pm 11.2$ & $289.5 \pm 14.5$ \\
\hline One day lactation milk yield, $\mathrm{kg}$ & $25.3 \pm 0.5$ & $25.0 \pm 0.4$ & $28.5 \pm 0.6^{* * * *}$ \\
\hline Average 305-day milk yield, $\mathrm{kg}$ & $7338.8 \pm 364.3$ & $7283.5 \pm 248.5$ & $7989.5 \pm 228.5^{*}$ \\
\hline Average milk yield for the three lactation, $\mathrm{kg}$ & $8081.5 \pm 621.6$ & $7917.0 \pm 342.5$ & $8715.6 \pm 273.9$ \\
\hline Milk yield for the three lactation, $\mathrm{kg}$ & $24244.6 \pm 158.2^{*}$ & $23751.0 \pm 166.7$ & $26146.9 \pm 227.9^{* * * *}$ \\
\hline
\end{tabular}

Following the results of three standard (305 days) and full lactations, the maximum average milk yield was also found in homozygous TT-animals. The milk yield for 305 days obtained from this group exceeded the milk yield indicator of heterozygous individuals by $706.0 \mathrm{~kg}$ $(8.8 \% ; \mathrm{p}<0.05)$, and of CC-type animals - by $650.7 \mathrm{~kg}$ $(8.1 \%)$.

The average amount of milk obtained during full lactation also prevails in cows with the TT genotype $(8715.6 \mathrm{~kg}$ ) versus $8081.5 \mathrm{~kg}$ from individuals with the CC genotype and $7917.0 \mathrm{~kg}$ from individuals with the TC genotype. The significant difference in this indicator between TT and TC animals was $798.6 \mathrm{~kg}$ or $9.2 \%$ (p < $0.05)$.

The effectiveness of using cows can be judged by the amount of milk production per day of life and lactation. In terms of the average daily milk yield, based on the number of milking days and the total milk yield for full lactation, in the context of the leptin gene polymorphism, we found that for all three lactations, a significant superiority in this indicator was assigned to a group of animals with a homozygous TT genotype.

The results obtained show that the difference between the average daily milk yield of animals with the TT and TC genotypes was: $2.1 \mathrm{~kg}$ for the first lactation $(8.7 \% ; \mathrm{p}<0.001), 2.4 \mathrm{~kg}$ for the second lactation $(9.9$ $\% ; \mathrm{p}<0.001), 3.5 \mathrm{~kg}$ for the third lactation $(12.3 \%$; $\mathrm{p}<0.001)$; and of animals with the TT and CC genotypes $-1.3 \mathrm{~kg}(5.4 \%$; $\mathrm{p}<0.01), 0.4 \mathrm{~kg}(1.6 \%)$ and $3.2 \mathrm{~kg}(11.2 \% ; \mathrm{p}<0.001)$ respectively.

During the second and third lactation, the average daily milk yield of the $\mathrm{CC}$ genotype subpopulation was higher than that of the TC genotype group by $0.8 \mathrm{~kg}(3.5$ $\% ; \mathrm{p}<0.05)$ and by $1.9 \mathrm{~kg}(7.6 \%$; $<<0.001)$, respectively.

In terms of milk yield, which was equal to three full lactations at the time of the research, individuals with the TT genotype were favourably distinguished. The advantage in this indicator with the group with the CC genotype was $1902.3 \mathrm{~kg}(7.3 \% ; \mathrm{p}<0.001)$, and the TC genotype was $2395.9 \mathrm{~kg}(9.2 \%$; $\mathrm{p}<0.001)$.

In the dynamics of three lactations of experimental cows with different genotypes of the leptin gene, it can be noted that regardless of the genotype, all groups have a shortened third lactation, as evidenced by equal milk yield indicators (Fig. 1).

Depending on the genotype of the LEP gene, there is a change in the nature of milk yield. After an increase in milk yield for the second lactation throughout the livestock under study, animals with the CC genotype show a decline in the third lactation below the level of milk yield obtained in the first lactation.

At the same time, the amount of milk produced from groups of cows with the TC and TT genotypes in the first lactation is significantly less. 


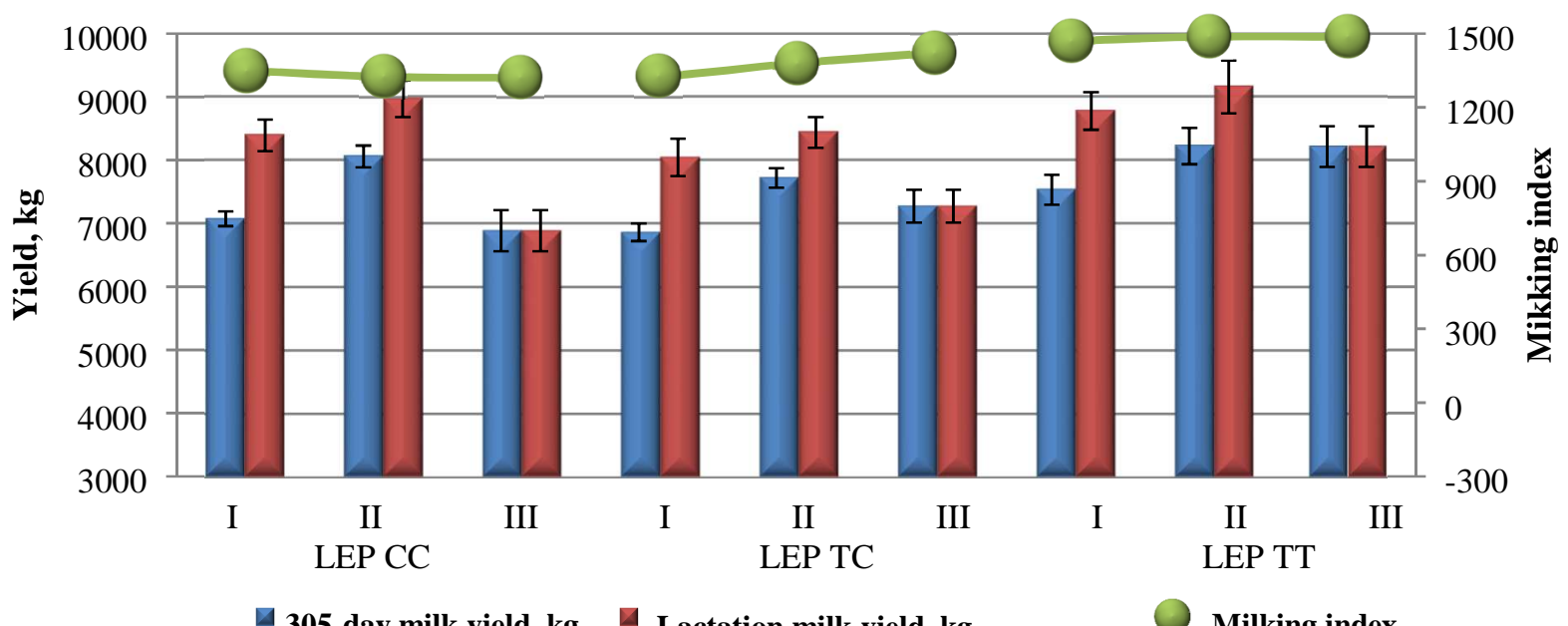

Fig. 1. Dynamics of milk productivity for the three lactation

The yield index in the context of three lactations shows different dynamics depending on the LEP genotype. Thus, it tends to decrease in cows with the CC genotype, and it tends to increase in cows with the TC genotype, while it remains without significant changes and has the highest level in animals with the TT genotype, which demonstrate the highest milk yield indicators.

The average daily milk yield for the entire population under study had a significant increase of $+1.1 \ldots+2.9 \mathrm{~kg}$ $(4.7 \ldots 11.6 \% ; \mathrm{p}<0.05 \ldots 0.001)$ during the second and third full lactation.

\section{Conclusion}

The results obtained indicate the genetic biodiversity of Holstein cattle population under study. The herd under study has three different genotypes. The best indicators for all three lactations were found in a group of animals with the TT genotype of the LEP gene. These individuals are characterized by increased milk yield, a high yield index, and tend to increase the average daily milk yield during three lactations.

Thus, it can be noted that the leptin gene affects milk production, lactation persistency and productive longevity of Holstein cattle and can be used as a genetic marker in selective breeding work.

This research was supported by FASO Russia proiect "Mobilizing the genetic resources of plants and animals. creating innovations that ensure the production of biologicallv valuable food products with maximum safety for human health and the environment" AAAA-A18-118031390148-1.

\section{References}

1. N. Zinoveva, P. Klenovitski, E. Gladyr, A. Nikichov, Modern methods of genetic control of breeding processes and certification of breeding material in animal husbandry, A training manual (Moscow, 2008)

2. Yu. A. Mikhireva, O.A. Bykova, News of the Orenburg State Agrar. Univer. 1(63), 142-144 (2017)

3. N.N. Sudgymer, O.A. Bykova, Zootechn. 2, 10 (2013)

4. E.V. Machulskaya, N.V. Kovalyuk, Yu.Yu. Shakhnazarova, V.F. Satsuk, A.A. Sermyagin, A.V. Dotsev, Coll. of sci. works SKNIIZH 1(6), 8288 (2017)

5. L.N. Chizhova, L.V. Kononova, G.N. Sharko, G.P. Kovaleva, Coll. of sci. works of VNIIOK 10, 113-117 (2017)

6. E.S. Corp, D.B. Conze, F. Smith, L.A. Campfield, Brain Res. 789, 40-47 (1998)

7. F.C. Buchanan, C.J. Fitzsimmons, A.G. Van Kessel, T.D. Thue, D.C. Winkelman-Sim, Sh.M. Schmutz, Genetic Select. Evolut. 34, 105-116 (2002) DOI: 10.1051/gse:2001006

8. L.A. Kalashnikova et al., Recommendations for the genomic assessment of cattle (Forest Glades, 2015)

9. J. Komisarek, J. Szyda, A. Michalak, Z. Dorynek, J. of Animal and Feed Sci. 14, 491-500 (2005)

10. F. Souza, M. Mercadante, L. Fonseca et al., Animal Sci. 88, 435-441 (2010). DOI: 10.2527/jas.2009-2174

11. E. Armstrong, F. Peñagaricano, R. Artigas et al., Archivos de Zootecn. 60(231), 707-716 (2011)

12. S. Ye, S. Dhillon, X. Ke, A. Collins, I. Day, Nucleic Acids Res. 29, 88e (2001)

13. X.-L. Wu, M.D. MacNeil, S. De et al., Genet. 125, 103-113 (2005). DOI 10.1007/s10709-005-5255-1

14. N.A. Balakirev, N.Yu. Safina, Yu.R. Yulmeteva et al., Russ. Agricult. Sci. 44(5), 460-464 (2018). DOI: $10.3103 / \mathrm{S} 1068367418050038$ 